\title{
PERAN ORANG TUA DALAM MEMBINA AKHLAK REMAJA (Studi di Kelurahan Air Duku, Rejang Lebong-Bengkulu)
}

\author{
Tria Masrofah 1)* \\ Fakhruddin 2) \\ Mutia 3) \\ 1,2,3, Program Studi Pendidikan Agama Islam \\ Institut Agama Islam Negeri (IAIN) Curup, Bengkulu \\ *E-mail: triamasrofah04@gmail.com
}

\begin{abstract}
In the concept of Islam, parents play an important role in the implementation of their children's religious education, and parents must even be able to be the role models for their children. For that reason, who became the subjects of this study were the parents in Air Duku village; concerning how was their role in fostering adolescents through education in family. This study used a qualitative approach, and the data were analyzed using the approach of Miles et al. This study found a conclusion that the parents' role was quite maximal in educating and instilling the values of Islamic education to foster adolescents' morals in Air Duku village. The implementation pattern of such a fostering effort is through the inculcation of religious values, guiding, supervising children/adolescents' behavior, and reprimanding them when doing bad things with the methods of habituation and giving advice, example, and attention.
\end{abstract}

Keywords: Parents' Role, Morals, Teenagers

\begin{abstract}
Abstrak
Dalam konsep Islam, orang tua memegang peran penting dalam pelaksanaan pendidikan agama pada anak-anak mereka, bahkan orang tua harus mampu menjadi teladan bagi anakanak tersebut, untuk itu yang menjadi subyek kasus penelitian ini adalah orang tua di Desa Air Duku, bagaimana peran mereka dalam membina akhlah remaja melelui pendidikan dalam keluarga. Penelitian ini menggunakan pendekatan kualitatif dan dianalisis dengan menggunakan pendekatan Miles dkk sehingga memperoleh simpulan bahwa peran orangtua cukup maksimal dalam mendidik dan menanamkan nilai-nilai Pendidikan Agama Islam guna membina akhlak pada remaja di Desa Air. Pola pelaksanaan pembinaan tersebut melalui penanaman nilai-nilai agama, membimbing, mengawasi perilaku anak dan menegur mereka apabila melakukan hal yang tidak baik dengan meode pembiasaan, nasihat, keteladanan dan perhatian.
\end{abstract}

Kata Kunci: Peran Orang Tua, Akhlak, Remaja

\section{PENDAHULUAN}

Agama Islam adalah agama yang universal yang dimana mengajarkan kepada umat manusia mengenai berbagai aspek kehidupan, baik duniawi maupun ukhrawi (Basinun, 2018; Ilyas, 2015; Nelliraharti \& Suri, 2020). Salah satu di antara ajaran Islam tersebut adalah mewajibkan kepada umat Islam untuk melaksanakan pendidikan, karena menurut ajaran Islam pendidikan adalah juga merupakan kebutuhan hidup manusia yang mutlak harus dipenuhi, demi untuk mencapai 
kesejahteraan dan kebahagiaan dunia dan akhirat (Sada, 2017). Dengan pendidikan itu pula manusia akan mendapatkan berbagai macam ilmu pengetahuan untuk bekal dan kehidupannya (Fadlillah, 2017; Saihu, 2020).

Pendidikan agama merupakan bagian pendidikan yang sangat penting yang berkenaan dengan aspek-aspek sikap dan nilai antara lain, akhlak, keagamaan dan sosial masyarakat. Agama memberikan motivasi hidup dalam kehidupan. Islam memandang pendidikan nilai sebagai inti dari pendidikan itu sendiri. Nilai yang dimaksud tersebut adalah akhlak, yakni nilai-nilai yang berasal dari ajaran Agama Islam yang bersumberkan Al-Quran dan Hadis (Imelda, 2017).

Pendidikan agama merupakan aspek pendidikan yang dibutuhkan oleh kaum muslimin. Agama merupakan pedoman hidup dan suatu sarana untuk menanamkan karakter yang baik, karena dengan itu seseorang menjadi terbiasa berfikir secara kritis dan dengan adanya dasar-dasar Pendidikan Agama Islam seseorang dapat berfikir secara murni dan tidak bingung jika menghadapi persoalan kehidupan serta meningkatkan keimanan, pemahaman, penghayatan, dan pengalaman peserta didik tentang agama Islam (Saihu \& Marsiti, 2019; Yasyakur, 2017a).

Pendidikan merupakan aspek yang sangat penting, karena pendididkan yang benar dan baik akan menjadi jembatan bagi seorang muslim untuk meninggikan derajat keimanan dan kualitas akhlaknya, seperti firman Allah dalam Q.S Al-Mujadilah 58: 11 "Apabila dikatakan "berdirilah kamu, niscaya allah akan menganggkat (derajat) orang-orang yang beriman diantaramu dan orang-orang yang diberi ilmu beberapa derajat". Menurut pandangan Islam, pendidikan harus mengutamakan pendidikan keimanan. Sejarah telah membuktikan bahwa pendidikan yang tidak atau kurang memperhatikan pendidikan keimanan akan menghasilkan lulusan yang kurang baik akhlaknya (Hair \& Hair, 2018).

Dalam upaya membentuk manusia Indonesia yang beriman dan bertakwa, maka pendidikan agama memiliki peranan yang sangat penting. Untuk itulah maka pendidikan agama wajib diberikan pada semua satuan, jenjang dan jenis pendidikan, baik melalui jalur sekolah maupun jalur luar sekoah. Pendidikan merupakan suatu proses untuk membentuk dan mengembangkan potensi yang dimiliki setiap manusia yang disesuaikan dengan suatu tujuan tertentu (Heri, 2018). Jika ditinjau dari perspektif amanah UU Nomor 20 tahun 2003 tentang Sistem Pendidikan Nasional Pasal 3 bahwa tujuan pendidikan adalah "Pendidikan Nasional berfungsi 
mengembangkan kemampuan dan membentuk watak serta peradaban bangsa yang bermartabat dalam rangka mencerdaskan kehidupan bangsa, bertujuan untuk berkembangnya pontesi peserta didik agar menjadi manusia yang: 1) beriman dan bertaqwa kepada Tuhan Yang Maha Esa; 2) berakhlak mulia; 3) sehat; 4) berilmu; 5) cakap; 6) kreatif; 7) mandiri; dan 8) menjadi warga yang demokratis serta bertanggung jawab" (Hendriana \& Jacobus, 2017; Rahardjo, 2017; Ulya et al., 2016; Widiansyah, 2018).

Mengacu pada tujuan pendidikan di Indonesia berdasarkan Undang-undang tersebut maka dapat diketahui bahwa salah satu dari tujuan pendidikan, yaitu mendidik peserta didik agar menjadi manusia yang berakhlak mulia. Adapun tujuan utama dalam pendidikan Islam adalah agar manusia memiliki gambaran tentang Islam yang jelas, utuh dan menyeluruh. Interaksi dalam diri manusia memberi pengaruh kepada penampilan, sikap, tingkah laku dan amalnya sehingga menghasilkan akhlak yang baik (Feri Musharyadi, 2017). Akhlak ini perlu dan harus dilatih melalui latihan membaca dan mengkaji al-Qur'an, sholat malam, puasa sunnah, selalu bersilaturahim dengan keluarga dan masyarakat (Andriyani, 2016). Semakin sering ia melakukan latihan, maka semakin banyak amalnya dan semakin mudah ia melakukan kebajikan. Selain itu latihan akan menghantarkan dirinya memiliki kebiasaan yang akhirnya menjadi gaya hidup sehari-hari (Hair \& Hair, 2018).

Pendidikan agama Islam adalah bimbingan jasmani dan rohani berdasarkan hukum-hukum Islam menuju kepada terbentuknya kepribadian yang utama menurut ukuran Islam Jika telah jelas bahwa al-Qur'an dan hadits rasul adalah pedoman hidup yang menjadi asas bagi setiap muslim, maka teranglah keduanya merupakan sumber akhlakul karimah (Fachri, 2014). Jika dilihat dari pengertian dan tujuan pendidikan Agama Islam di atas menunjukkan bahwa pendidikan Agama Islam sangatlah diperlukan dalam menunjang dan meningkatkan peran serta mutu pendidikan lewat kegiatan keagamaan dalam meningkatkan akhlak dan budi pekerti yang mulia (Ridwan \& Ladamay, 2020).

Proses pendidikan agama Islam menumpukan pendidikan akhlak menjadi prioritas yang utama (Munthoha \& Wekke 2017) yang mana pendidikan agama merupakan faktor yang sangat penting untuk menyelamatkan anak-anak, remaja ataupun orang dewasa dari pengaruh buruk budaya asing yang bertentangan dengan budaya Islam yang saat ini sudah banyak mempengaruhi bangsa Indonesia, terutama 
generasi muda (Hair \& Hair, 2018; Munthoha \& Wekke, 2017). Mengacu pada undangundang SISDIKNAS Nomor 20 tahun 2003 Bab II pasal 3, rumusan tujuan pendidikan tersebut sebenarnya lebih menekankan pada aspek afektif (Munthoha \& Wekke, 2017; Supriatna, 2018). Sehingga pembelajaran afeksi sering terabaikan kurang mendapatkan proporsi yang cukup. Ki Hajar Dewantara menyatakan bahwa: Maksud pendidikan adalah sempurnanya hidup manusia sehingga bisa memenuhi segala keperluan hidup lahir batin. Pengetahuan, kepandaian janganlah dianggap maksud dan tujuan,tetapi alat, perkakas, lain tidak (Hidayah, 2015; Magta, 2013). Bunganya, yang kelak akan jadi buah, itulah yang harus diutamakan. Buahnya pendidikan, yaitu matangnya jiwa, yang akan dapat mewujudkan hidup dan penghidupan yang tertib dan suci dan manfaat bagi orang lain (Arifin \& Karimah, 2018; Rohman, 2016).

Akhlak tidak akan tumbuh tanpa diajarkan dan dibiasakan (Daheri \& Warsah, 2019). Oleh sebab itu pendidikan agama, selain sebagai ilmu secara bertahap juga harus diikuti secara terus menerus bentuk pengalamannya. Orang tua memegang peranan penting dalam pelaksanaan pendidikan agama dirumah. Namun orang tua diharapkan menjadi teladan dalam beribadah dan berakhlak (Warsah, 2018, 2020).

Pendidikan yang utama dan pertama adalah pendidikan dalam keluarga. Dalam hal ini keluarga mempunyai peran dalam pembentukan akhlak anak, oleh karena itu keluarga harus memberikan pendidikan atau mengajar anak tentang akhlak mulia atau baik. Hal itu tercermin dari sikap dan perilaku orang tua sebagai teladan yang dapat dicontoh oleh anak (Abidin et al., 2018). Seringkali terjadi pembelajaran PAI dilakukan dengan tidak melibatkan komponen-komponen lain terutama orang tua dan masyarakat, padahal jumlah jam Mapel PAI hanya dua jam seminggu sehingga pembelajaran hanya mengejar aspek kognitif saja (Rohman, 2016), karena penanaman nilai-nilai akhlak memerlukan tanggung jawab bersama semua komponen: sekolah, masyarakat dan orang tua (Nurfalah, 2018).

Peran Pendidikan Agama Islam dalam Keluarga dan Masyarakat yang dimilikinya itu untuk kebaikan masyarakat, lingkungan dan bangsanya (Izzah, 2018). Pendidikan agama ialah usaha-usaha secara sistematis dan pragmatis untuk membantu anak didik agar mereka hidup sesuai dengan ajaran agama dan suatu usaha bimbingan dan asuhan terhadap anak didik agar nantinya dapat mengamalkan ajaran agamanya (Hair \& Hair, 2018). Jadi dalam pendidikan agama yang lebih dipentingkan adalah sebagai pembentukan kepribadian anak, yaitu menanamkan tabiat yang baik agar anak didik 
mempunyai sifat yang baik dan berkepribadian yang utama. Pendidikan Islam sebagai medium transformasi nilai Islam serta pembentukan dan pengkondisian sikap dan perilaku manusia perlu ditata. Melalui pola ini pendidikan Islam dapat memantapkan perannya dalam melahirkan tatanan kehidupan yang sesuai dengan fitrah manusia (Hair \& Hair, 2018).

Berdasarkan uraian di atas, dapat disimpulkan bahwa keluarga memiliki peran penting terhadap Pendidikan Agama. Pendidikan Agama Islam dalam keluarga adalah pendidikan aqidah, ibadah dan akhlak yang diberikan oleh orang tua dan guru ngaji atau guru agama kepada anak. Pendidikan agama Islam merupakan bagian integral dari pembelajaran seluruh umat Islam baik dipakai dari pendidikan formal maupun non formal, serta merupakan bagian yang amat penting dalam rangka pemberian bimbingan dan pembinaan pada anak remaja agar mampu memahami, menghayati dan mengamalkan agama Islam.

Sedangkan remaja adalah periode transisi antara masa anak-anak ke masa dewasa atau masa usia belasan tahun, atau jika seseorang menunjukkan tingkah laku tertentu seperti susah diatur, mudah terangsang perasaannya dan sebagainya remaja merupakan aset penting dalam Islam(Khasanah et al., 2019). Masa muda adalah masa yang penuh kekuatan dan dinamisme yang memancar. Sejarah mencatatkan bahawa kegemilangan Islam bermula dari tangan generasi muda yang memperjuangkan agama yang dibawakan oleh baginda Nabi Muhammad SAW ini (Riantory, 2019). Oleh karena itu, seharusnya remaja ini dididik, dibimbing, dan diasuh dari kecil dengan pendidikan yang tersusun rapi untuk melahirkan generasi yang berakhlak mulia. Sebaiknya mereka diberi bimbingan agama agar menjadi pedoman hidup baginya.

Masa remaja adalah masa peralihan yang ditempuh oleh seseorang dari kanakkanak menuju dewasa. Dapat dikatakan, bahwa masa remaja adalah perpanjangan masa kanak-kanak sebelum mencapai masa dewasa (Munjiat, 2018) Remaja diharapkan mampu menjadi tulang punggung negara yang potensinya memerlukan pembinaan yang optimal untuk menyongsong masa depan. Agar pembinaan ini dapat berhasil dengan optimal, maka diperlukan kerja sama dari berbagai pihak. Selain itu, juga harus diperhatikan karakteristik remaja itu sendiri, karena remaja sedang dalam masa transisi atau pancaroba sehingga memiliki sifat-sifat yang belum matang seperti yang dimiliki orang dewasa (Asroruddin, 2016). 
Oleh karena itu, adanya pendidikan Islam bagi kalangan remaja sangatlah penting. Pendidikan harus dilakukan baik di sekolah, keluarga atau lingkungan sekitar. Pendidikan Islam diharapkan menjadi benteng atau suatu pegangan dalam proses penanaman akhlak, karena sejatinya, konsep pendidikan Islam adalah menjadikan manusia berakhlak mulia. Adanya Pendidikan Agama Islam di sekolah maupun di luar sekolah, secara dini anak remaja diperkenalkan dengan aturan mulia serta normanorma luhur yang dapat diterapkan dalam kehidupan sehari-hari, baik yang meliputi cara yang berhubungan dengan masyarakat sekitarnya, yang akhirnya diharapkan menjadi manusia yang bertaqwa kepada Allah SWT (Syahroni, 2017). Dengan keimanan dan ketaqwaan akan terbentuk manusia berakhlak yang memiliki semangat kebangsaan yang tinggi untuk dijadikan modal utama penggerak pembangunan diri pribadi maupun pembangunan agama, bangsa dan Negara (Ahmadi, 2017).

Jadi, berpegang pada prinsip dan pendirian yang kukuh berlandaskan ajaran agama dapat mencegah seseorang remaja dari pada dipengaruhi oleh unsur-unsur pergaulan bebas yang tidak sehat dan melampaui batasan. Sesungguhnya pendidikan agama yang tanamkan sejak kanak-kanak mampu membentuk perkembangan diri remaja yang positif serta mempunyai nilai-nilai murni dalam jiwa mereka. Pendidikan agama juga dilihat mampu menolak perlakuan negatif dan unsur-unsur yang bertentangan dengan ajaran agama. Pandangan ini mengambarkan bahawa betapa pentingnya pendidikan agama ke arah pembentukan sahsiah dan akhlak yang sempurna dalam kalangan remaja (Ghani \& Musa, 2018; Yahya \& Nasrun, 2016).

Seperti halnya para orangtua di kelurahan Air Duku yang mengajarkan langsung kepada anaknya mengenai nilai-nilai agama. Seperti mengajak untuk belajar membaca Al-Quran setelah melakukan ibadah shalat magrib, berpakaian yang sopan, berbicara yang santun, dan hormat kepada orang yang lebih tua dengan Cara ini dinilai sangat efektif guna untuk membangun akhlak remaja dan dengan cara ini orangtua juga telah memenuhi kewajiban dan tanggung jawabnya untuk menjadi tauladan yang baik bagi anak-anaknya. (Observasi, 23 Maret 2020).

Oleh karena itu, mengingat pentingnya pendidikan Islam terutama bagi generasi muda, semua elemen bangsa, terutama guru pendidikan Islam, perlu membumikan kembali pendidikan Islam disekolah-sekolah baik formal maupun informal. Berangkat dari problem yang telah dipaparkan di atas, penelitian ini berusaha menemukan gambaran tentang bagaimana orang membangun akhlak remaja melalui Pendidikan 
Agama Islam. Agar memudahkan dalam pengumpulan daa perlu formulasikan dalam bentuk tujuan penelitian yaitu: gamabaran tentang peran orang tua dalam membina akhlak pada remaja di masyarakat keluaran Air Duku dan cara yang dilakukan oleh orang tua dalam membina akhlak remaja.

\section{METODE}

Penelitian ini merupakan penelitian lapangan yang bersifat deskriptif kualitatif yaitu Penelitian yang secara langsung ditujukan kepada objek penelitian untuk memperoleh data yang diperlukan (Colorafi \& Evans, 2016). Dengan demikian yang dimaksud dengan penelitian deskriptif merupakan penelitian yang berusaha mendeskripsikan dan menginterpretasikan sesuatu, misalnya kondisi atau hubungan yang ada, pendapat yang berkembang, proses yang sedang berlangsung, akibat atau efek yang terjadi, atau tentang kecendrungan yang tengah berlangsung (Setiawan, 2018; Sugiarto, 2017). Penelitian ini dengan analisis kualitatif yang tidak dapat diukur dengan angka (Raco, 2018). Data dikumpulkan melalui wawancara, observasi dan dokumentasi (Moleong, 2010). Tujuan dari penelitian ini adalah untuk mengetahui gambaran tentang peran pendidikan agama Islam itu sendiri dalam membangun akhlak dan cara membangun akhlak pada remaja itu sendiri.

Subyek dalam penelitian ini adalah orang tua di kelurahan Air Duku. Setelah data terkumpul dilakukan pemilihan data untuk disajikan dalam hasil penelitian dan dianalisis dalam pembahasan selanjutnya diperoleh simpulan sebagai jawaban permasalahan tentang peran orang tua dalam membina akhlak pada remaja di Kelurahan Air Duku (Hashimov, 2015; Miles et al., 2014).

\section{HASIL DAN PEMBAHASAN}

Paparan hasil penelitian tentang peran Pendidikan Agama Islam dalam keluarga untuk membina akhlak pada remaja di kelurahan Air Duku yang dilakukan melalui observasi dan wawancara langsuk kepada subyek dan informan penelitian guna memperoleh gambaran konkret tentang fokus masalah yang telah diajukan dalam pendahuluan.

\section{Peran orang tua dalam membina akhlak pada remaja}

Membina anak pada hakikatnya bertumpu pada tiga upaya, yaitu; memberi teladan, memelihara, dan membiasakan anak sesuai dengan perintah (Daheri \& Warsah, 2019). Pertama Orang tua berperan sebagai suri teladan bagi anaknya, 
sebelumnya menjadi teladan, orang tua hendaknya memahami dan mengamalkannya terlebih dulu. Inilah sikap yang dicontohkan oleh Rasulullah Saw. Pengamalan terhadap ajaran agama oleh orang tua secara tidak langsung telah memberikan pendidikan yang baik terutama akhlak. memelihara anak. Tanggung jawab ini fokus pada pemeliharaan fisik melalui makanan dan minuman dan pengembangan potensi anak. Ketiga, membiasakan anak sesuai dengan perintah agama. Tugas ini fokus pada pembiasaan aturan agama kepada anak. Aturan agama yang berkaitan dengan syariat dan sistem nilai dalam bermasyarakat (Padjrin, 2016).

Untuk memperoleh data tentang peran orang tua peneliti mencoba mewawancarai bapak Joniswan yang mengatakan bahwa "orangtua wajib mendidik dan mampu menjadi suritauladan bagi anakya, pendidikan yang diberikan haruslah tepat dan benar seyogyanya orang tua harus tepat dalam menentukan apa yang mesti harus diajarkan pada anak-anaknya, yaitu menanamkan nilai-nilai pendidikan Islam" (Wawancara 03 Maret 2020).

Dapat dipahami bahwa pendidikan Agama Islam berperan membentuk manusia yang beriman dan bertaqwa kepada Allah SWT, yaitu dengan mengamalkan ajaran agamanya dalam kehidupan sehari-hari baik dalam kehidupan pribadi mapun masyarakat yang berlandaskan alqur'an dan hadist yang menjadi acuan atau pedoman dalam hidup. Penjelasan ini juga sejalan ibu Laila menyatakan "Pembiasaan dengan syariat seperti puasa sunah maupun puasa wajib, sholat dan pembiasaan dengan sistem nilai berkaitan erat dengan akhlak anak seperti berbahasa yang sopan, berbicara santun kepada orang yang lebih tua, makan dan minum menggunakan tangan kanan" (Wawancara 05 Maret 2020).

Secara prinsip, setiap orang tua pasti menginginkan keberhasilan dalam pendidikan anak-anaknya. Keberhasilan dalam mendidik tentunya tidak akan dapat terwujud tanpa adanya usaha keras dan peran dari orang tua itu sendiri (Ginanjar, 2017). Selanjutnya, Pendidikan Islam adalah solusi untuk mengubah etika, akhlak, dan moral. Agama memberikan motivasi hidup dalam kehidupan. Islam memandang pendidikan nilai sebagai inti dari pendidikan itu sendiri. Nilai yang dimaksud tersebut adalah akhlak, yakni nilai-nilai yang berasal dari ajaran Agama Islam yang bersumberkan Al-Quran dan Hadis (Imelda, 2017).

Terkait dengan konsep di atas, pada data observasi menunjukkan bahwa para orangtua Desa tersebut mengetahui kewajibannya sebagai orang tua. Peneliti melihat 
bahwa memang para orang tua menanamkan Pendidikan Islami melalui pembiasaan menjalankan ajaran Islam seperti ibadah wajib dan memanankan nilai-nilai Islami baik di rumah maupun di tengah masyarakat (Observasi 27 Maret 2020).

Merek memahami dengan baik bahwa tujuan utama dalam pendidikan Islam adalah agar manusia memiliki gambaran tentang Islam yang jelas, utuh dan menyeluruh. Interaksi di dalam diri manusia memberi pengaruh kepada penampilan, sikap, tingkah laku dan amalnya sehingga menghasilkan akhlaq yang baik. Tujuan dari Pendidikan Islam itu sendiri selaras dengan pendapat salah satu orang tua, Sebagaimana yang diungkapkan oleh bapak Mashudi bahwa "Akhlaq ini perlu dan harus dilatih melalui latihan contohnya membaca dan mengkaji Al Qur'an, sholat malam, shoum (puasa) sunnah, bertatakrama yang baik terhadap orang yang lebih tua, selalu bersilaturahim dengan keluarga, teman dan masyarakat sekitar, latihan akan menghantarkan dirinya memiliki kebiasaan yang akhirnya menjadi gaya hidup seharihari. Semakin sering ia melakukan latihan, maka semakin banyak amalnya dan semakin mudah ia melakukan kebajikan" (Wawancara 02 April 2020).

Pendidikan Islam memiliki peran penting dalam mengaktualisasikan nilai-nilai keIslaman dalam kehidupan masyarakat. Pendidikan Isla dalam aktualisasi penyelenggaraanya pada lembaga pendidikan jenjang dasar maupun menengah perlu mensinkronkan dengan realitas perkembangan kehidupan sehingga output pendidikan tidak mengalami distorsi nilai. Pendidikan Islam sebagai bagian dari Islam menjadikan landasan pada dasar-dasar ajaran Islam yang rahmatan lil'alamin. Dasardasar pembentukan dan pengembangan pendidikan agama Islam yang pertama dan utama adalah al-Qur'an dan al-Hadits, selanjutnya nilai-nilai sosial kemasyarakatan yang tidak bertentang an dengan ajaran-ajaran al-Qur'an dan sunnah atas prinsip mendatangkan kemanfaatan dan menjauhkan kemudharatan bagi manusia (Kholidah, 2015).

Pengertian nilai dan pendidikan Islam dapat didefinisikan bahwa nilai-nilai pendidikan Islam adalah kumpulan dari prinsip-prinsip hidup yang saling terkait yang berisi ajaran-ajaran guna memelihara dan mengembangkan fitrah manusia serta sumber daya manusia yang ada padanya menuju terbentuknya manusia seutuhnya (insan kamil) sesuai dengan ajaran Islam. Pokok-pokok nilai pendidikan Islam yang utama yang harus ditanamkan pada anak yaitu nilai pendidikan i'tiqodiyah, nilai pendidikan amaliyah, nilai pendidikan khuluqiyah (Bali \& Fadli, 2019). 
Nilai Pendidikan I'tiqodiyah merupakan nilai yang terkait dengan keimanan seperti iman kepada Allah SWT, malaikat, rasul, kitab, hari akhir dan takdir yang bertujuan menata kepercayaan individu. Iman berasal dari bahasa Arab dengan kata dasar amanayu'minu imanan artinya beriman atau percaya (Bali \& Fadli, 2019). Pelaksanaan Pendidikan Agama Islam kepada Anak Remaja adalah dalam bentuk mengajarkan pendidikan agama dan membimbing pelaksanaan perintah agama, mengawasi tingkah laku anak dan menegur mereka apabila melakukan hal yang tidak baik (Khoiri, 2018; Yasyakur, 2017b).

Pendidikan keimanan merupakan aspek utama pendidikan dari orang tua, karena iman bagian dari keIslaman. Keimanan dapat dijadikan suatu landasan bagi anak, dengan demikian kelak ketika telah dewasa akan menjadi insan yang beriman kepada Allah SWT menjalankan perintah agama dan menjauhi larangan-Nya. Dengan demikian keimanan yang kuat dapat menjadi benteng dari perilaku buruk. Keimanan yang kuat akan membuahkan akhlak-akhlak yang terpuji

Nilai Pendidikan Amaliyah. Nilai pendidikan Amaliyah merupakan nilai yang berkaitan dengan akhlaq atau tingkah laku. Nilai pendidikan amaliyah diantaranya: a) Pendidikan Ibadah Ibadah merupak bukti nyata bagi seorang muslim dalam meyakini dan mempedomani aqidah Islamiyah (Siregar, 2018). Pembinaan ketaatan beribadah kepada anak dimulai dari dalam keluarga. Sejak dini, anak-anak harus diperkenalkan dengan nilai ibadah, seperti diajarkan melafalkan surat-surat pendek dari al-Qur'an untuk melatih lafal-lafal agar fasih mengucapkannya, karena membaca al-Qur'an adalah ibadah.

Kemudian juga anak-anak diajarkan mendirikan shalat, agar ketika anak mulai baligh, tidak perlu bersusah payah belajar shalat. Ibadah tersebut merupakan salah satu pendidikan dari Allah untuk hamba-Nya untuk menjadi baik dan bermanfaatdi dunia bagi agama, manusia, dan alam semesta serta baik di akhirat dengan balasan surga dan limpahan kebaikan.

Pendidikan Muamalah ialah pendidikan yang berkaitan antara manusia baik secara individu maupun kelompok. Pendidikan muamalah ini meliputi (Bali \& Fadli, 2019):

a. Pendidikan Syakhsiyah, ialah pendidikan yang berkaitan dengan perilaku individu, seperti masalah perikahan, hubungan suami istri dan keluarga yang bertujuan untuk membangun keluarga yang sakinah, mawaddah dan sejahtera. 
b. Pendidikan Madaniyah, Pendidikan ini memuat tentang perdagangan seperti gaji, gadai yang bertujuan untuk mengelola harta benda hak-hak indvidu atau kelompok

c. Pendidikan Jana'iyah, Pendidikan ini yang berhubungan dengan pidana atas pelanggaran yang dikerjakan oleh seseorang, yang bertujuan untuk keadilan sosial, baik berkaitan dengan hartabenda, kehormatan, maupun hak-hak individu yang lain. Contoh: Pelanggaran HAM.

d. Pendidikan Murafa'at, Pendidikan ini berhubungan dengan acara seperti peradilan, saksi maupun sumpah yang bertujuan untuk menegakkan keadilan diantara anggota masyarakat. Contoh: Pengadialan cerai, sengketa tanah, kasus pencurian

e. Pendidikan Dusturiyah, Pendidikan ini berkaitandengan undang-undang negara yang mengatur hubungan rakyat dengan pemerintah yang bertujuan untuk stabilitas bangsa.

f. Pendidikan Duwaliyah, Pendidikan ini yang berhubungan dengan tata negara seperti tata negara Islam, tata negara tidak Islam, wilayah perdamaian dan wilayah perang, dan hubungan muslim di negara lain yang bertujuan untuk perdamaian dunia.

g. Pendidikan Iqtishadiyah, Pendidikan ini berhubungan dengan perkonomian individu dan negara, hubungan yang miskin dengan yang kaya yang bertujuan untuk keseimbangan dan pemerataan pendapatan. Contoh: Memberikan sedekah kepada seorang fakir.

Nilai Pendidikan Khuluqiyah Pendidikan ini merupakan pendidikan yang berkaitan dengan akhlak yang bertujuan membersihkan diri dari perilaku rendah dan menghiasi diri dengan perilaku terpuji. Pendidikan akhlak merupakan pendidikan yang paling utama dalam Islam, karena pendidikan akhlak merupakan pendidikan yang membawa kesuksesan, oleh karena itu Jika tidak dididik atau diperhatikan secara benar oleh para orang tua, maka nantinya anak tumbuh dalam keadaan akhlak yang kurang baik. Sebab, seorang anak pada hakikatnya telah tercipta dengan kemampuan untuk menerima kebaikan maupun keburukan. Kedua orang tuanyalah yang membuatnya cenderung kearah salah satu dari keduanya (Zamroni, 2017).

Sementara pendapat para orang tua tentang peran Pendidikan Agama Islam dalam membangun akhlak remaja bapak Amrullah mengatakan " akhlak merupakan asas yang paling utama dalam pendidikan Islam, karena dalam ajaran Islam memuat 
tentang bagaimana cara mendidik anak agar kelak menjadi anak yang sukses dunia dan akhirat, yang memuat pendidikan nilai yang dimaksud nilai disini adalah akhlak, seperti bagaimana cara berperilaku sopan santun terhadap orang yang lebih tua dan bagaima cara berbicara kepada yang lebih muda, seperti penanaman nilai pendidikan khuluqiyah yang merupakan bagian yang terpenting dalam kehidupan sehari-hari, karena orang yang tidak memiliki akhlak akan menjadikan dirinya yang dapat merugikan orang lain. Pendidikan akhalak merupakan pendidikan yang paling utama, oleh karena itu didiklah anak-anak sebagai penerus bangsa dengan akhlak yang baik dengan berlandasakan alqur'an dan hadist seprti yang diajarkan oleh nabi Muhammad SAW" (Wawancara 01 Juni 2020).

Pendidikan Agama Islam adalah bimbingan jasmani dan rohani yang berdasarkan hukum-hukum agama Islam menuju kepada pembentukan pribadi dan jiwa sesuai dengan anjuran agama Islam. Selain itu, Pendidikan Agama Islam juga merupakan salah satu faktor yang membentuk kepribadian yang luhur bagi peserta didik. Selain membentuk kepribadian yang luhur, pendidikan agama Islam juga bertujuan menanamkan keimanan pada diri peserta didik yang tercermin dalam kehidupan mereka sehari-hari. Proses yang dilakukan untuk menciptakan manusia-manusia yang seutuhnya beriman dan bertakwa kepada Tuhan serta mampu mewujudkan eksistensinya sebagai khalifah allah di muka bumi, yang bersandar kepada ajaran AlQuran dan Sunnah, maka tujuan dalam konteks ini berarti terciptanya insan kamil setelah proses berakhir. Atas daras itu mengapa pendidikan agama Islam mempunyai peran penting dalam membangun akhlak yang tidak terlepas dari tujuan pendidikan agama Islam itu sendiri.

Mengingat pentingnya Pendidikan Islam terutama bagi generasi muda, semua elemen bangsa, terutama guru pendidikan Islam, perlu membumikan kembali pendidikan Islam di sekolah-sekolah baik formal maupun informal. Pendidikan agama dapat merubah masyarakat jahiliyah menjadi umat yang baik. Pendidikan Islam mempunyai ciri pembentukan pemahaman Islam yang utuh dan menyeluruh, pemeliharaan apa yang telah dipelajarinya, pengembangan atas ilmu yang diperolehnya dan agar tetap pada rel syariah. Hasil dari pendidikan Islam akan membentuk jiwa yang tenang, akal yang cerdas dan fisik yang kuat serta banyak beramal. 
Kemudian untuk memastikan kembali tentang peran pendidikan dalam membangun akhlak pada remaja peneliti kembali mewawancarai bapak masduki "pendidikan dengan memberikan teladanan adalah penopang dalam upaya meluruskan kebengkokak akhlak anak Dengan demikian terlihat bahwa nilai pendidikan yang terkandung dalam pendidikan amaliyah yang berkaitan dengan akhlak dan perilaku, sejalan dengan nilai pendidikan amaliyah bahwa pendidikan yang orang tua tanamkan dalam membangun akhlak anak-anak mereka yaitu dengan memberikan teladanan pembinaan ibadah, dengan mengenalkan nilai-nilai ibadah seperti membaca al-qur'an, menghafal ayat-ayat pendek. (Wawancara 02 juni 2020).

Dengan demikian, maka pengertian Pendidikan Agama Islam berdasarkan rumusan di atas adalah pembentukan perubahan sikap dan tingkah laku sesuai dengan petunjuk ajaran agama Islam. Sebagaimana yang pernah dilakukan Nabi dalam usaha menyampaikan seruan agama dengan berdakwah, menyampaikan ajaran, memberi contoh, melatih keterampilan berbuat, memberi motivasi dan menciptakan lingkungan sosial yang mendukung pelaksanaan ide pembentukan pribadi muslim. Untuk itu perlu adanya usaha, kegiatan, cara, alat, dan lingkungan hidup yang menunjang keberhasilannya.

Pendidikan Islam bertujuan membentuk pribadi muslim seutuhnya dan mengembangkan seluruh potensi manusia baik berupa jasmani maupun rohani ketika kita menyebut pendidikan agama Islam, maka akan mencakup dua hal, yaitu: a) Mendidik peserta didik untuk berperilaku sesuai dengan nilai-nilai atau akhlak Islam b) Mendidik peserta didik untuk mempelajari materi ajaran agama Islam seperti yang tercantum pada tujuan pendidikan Islam itu sendiri (Syafe'i, 2015).

Pendidikan agama Islam diharapkan dapat menghasilkan manusia yang berupaya menyempurnakan iman dan akhlak serta aktif membangun peradapan dan keharmonisan kehidupan khususnya dalam membangun akhlak anak. Sehingga manusia seperti itu diharapkan tangguh dalam menghadapi tantangan hambatan dan perubahan yang muncul dalam pergaulan masyarakat, baik lingkup lokal dan nasional. Pendidikan Islam dengan istilah Islamic Studies, secara sederhana dikatakan sebagai usaha untuk mempelajari hal-hal yang berhubungan dengan agama Islam (Izzah, 2018).

Berbagai data dari hasil observasi dan wawancara diatas diperolah jawaban bahwa peran orangtua sangat penting dalam mendidik dan menanamkan nilai-nilai 
pendidikan agama Islam dalam membina akhlak pada remaja dengan penanaman pokok-pokok nilai pendidikan yang ditanamkan oleh orang tua diantaranya nilai pendidikan amaliyah yaitu merupakan nilai pendidikan yang berkaitan dengan akhlak dan perilaku seperti pendidikan ibadah, serta pendidikan nilai khuluqiyah merupakan nilai pendidikan yang berkaitan dengan etika akhlak yang bertujuan membersihkan diri dari perilaku rendah dan menghiasi diri dengan perilaku terpuji.

\section{Cara Orang Tua dalam Membangun Akhlak Remaja}

Berdasarkan hasil wawancara orang tua yang dilakukan di kelurahan Air Duku bahwa Akhlak merupakan cerminan dari iman yang mencakup dalam segala bentuk perilaku. agar tercipta remaja muslim yang berakhlak mulia, maka orang tua berperan sangatlah penting untuk mewujudkannya. Dalam hal ini, suatu faktor penting yang memegang peranan menentukan dalam kehidupan remaja yakni agama. Sebab agama adalah latihan akhlak bagi jiwa manusia dan persoalan remaja, maka upaya mengatasinya dapat dilakukan melalui pendidikan akhlak. Karena dalam pendidikan akhlak dititik beratkan pada pembentukan mental remaja agar memiliki pribadi yang bermoral, budi pekerti yang luhur dan bersusila.

Hal ini sebagaimana yang dikatakan oleh bapak mashudi yang mempunyai anak laki-laki berusia 13 tahun "saya sebagai orang tua selalu mengajarkan anak saya untuk selalu beribada kepada allah SWT dengan menganjurkan untuk shalat lima waktu" (Wawancara 04 Juni 2020). Hal serupa juga dikatak oleh bapak soleh yang mempunyai anak berusia 14 tahun bahwasanya beliau mengajarkan untuk selalu taat beribadah kepada allah dengan mendirikan shalat lima waktu. Kemudian dari hasil wawancara yang telah dilakukan peneliti mencoba mengamati kegiatan yang dilakukan orang tua terhadap anak-nak mereka, dan ternyata hal itu benar adanya. Orang tua disaat tiba waktunya sholat memerintahkan anak-anak mereka untuk melaksanakan sholat terlebih dahulu, da nada sebagian dari orang tua yang mengajak anak-anak mereka untuk melaksanakan sholat dirumah ataupun dimasjid (Observasi 05 Juni 2020).

Salah satu upaya lain yang dilakukan oleh orang tua dalam membangun akhlak anak mereka yaitu memberikan contoh teladan yang baik, dari hasil wawancara dan observasi kepada orang tua diantaranya sebagaimana yang dikatakan oleh bapak Samidi yang mempunyai anak umur 14 tahun "saya selaku orang tua haruslah memberikan contoh yang baik terhadap anak-anak saya, karena sebagai orang tua akan menjadi panutan bagi anak-anak saya, sebagai contoh saya menyuruh anak untuk 
sholat lima waktu dan melaksanakan puasa sayapun ikut melaksanakan bukan hanya menyuruh saja, saya selalu mengajarkan anak untuk berprilaku sopan terhadap orang yang lebih tua" (Wawancara 5 Juni 2020). Selanjutnya peneliti memperkuat dengan hasil pengamatan yang dilakukan bahwa, pihak orang dalam ini bersifat mengajak anak-anak mereka untuk berperilaku sopan, dan dengan contoh melakukan terlebih dahulu melakukan kegiatan yang mereka perintahkan kepada anak-anaknya (Observasi 05 Juni 2020)

Berdasarkan wawancara yang telah dilakukan oleh bapak joniswan bahwasanya beliau mengatakan bahwa "setiap orang tua menginginkan anak yang mempunyai akhlak terpuji oleh karena itu sebagai orang tua haruslah mendidik dan membiasakn anak untuk berbuat baik dan selalu menjalankan perintah Allah SWT, saya selalu berusaha mengingatkan anak saya untuk tidak meninggalkan sholat dan saya biasakan kepada anak saya mulai sejak kecil untuk shalat berjamaah dimasjid bila tiba waktunya sholat" (Wawancara 05 Juni 2020). Saya selaku orang tua selalu memberi nasehat kepada anak saya bilamana menurut saya apa yang dilakukan mereka kurang baik, itupun jikalau mereka masih melakukan pertama dan kedua kalinya, dan jika sudah saya nasehati tetapi masih tetap dilakukan apa yang menurut saya salah, maka saya akan hukum, dan hukuman yang saya brikan bermacam-macam (Wawancara 06 Juni 2020). Sebagaimana yang dilakukan oleh ibu fajar bahwasnya saya selaku orang tua harus tahu betul dengan siapa anak saya bergaul atau berteman, saya harus mengetahui teman-teman anak saya dirumah maupun disekolah (Wawancara 06 Juni 2020)

Berdasarkan dari hasil wawancara di atas bahwa pihak orang tua telah melakukan upaya memberikan contoh atau tauladan pada anaknya agar selalu baik dalam berperilaku. Untuk memperkuat data di atas dari keterangan yang didapat bahwa Radhya salah satu anak dari bapak Joniswan melakukan apa yang diungkapkan oleh bapak tersebut. Sebagai orang tua sesulit dan susah apapun tentu saja kami selalu berusaha untuk selalu mengarahkan anak-anak kami agar selalu mempunyai akhlak yang baik, upaya yang kami lakukan beragam macam, diantaranya kalau dirumah saatsedang bersama keluarga (anak-anak) kami selaku orangtua berusaha mengajak untuk shaalat, mengaji, dan memberikan nasehat.

Berdasarkan keterangan dari hasil wawancara di atas yang dilakukan orang tua semua pernyataan hampir sama dan bila dilihat dengan jelas upaya yang dilakukan 
oleh orangtua di kelurahan Air Duku bahwa orang tua telah berusaha dalam membangun akhlak anak dengan cara pendekatan terhadap anak, seperti menyuruh anak dalam berbuat baik, bertutur sopan terhadap orang yang lebih tua, memberikan contoh dan teladan yang baik hingga memberikan nasihat dan bahkan bemberi peringatan dengan cara menghukm anak. Jadi dapat disimpulkan bahwa upaya/cara atau meode orang tua dalam membangun akhlak anak-anak mereka sama saja dengan para orang tua yang lain yaitu dengan cara pembiasaan, nasihat, keteladanan dan perhatian.

\section{KESIMPULAN DAN SARAN}

\section{Kesimpulan}

Peran orangtua cukup maksimal dalam mendidik dan menanamkan nilai-nilai Pendidikan Agama Islam dalam membina akhlak pada remaja di Desa Air Duku seperti dengan penanaman pokok-pokok nilai pendidikan yang ditanamkan oleh orang tua diantaranya nilai pendidikan amaliyah yaitu merupakan nilai pendidikan yang berkaitan dengan akhalak dan perilaku seperti pendidikan ibadah, serta pendidikan nilai khuluqiyah merupakan nilai pendidikan yang berkaitan dengan etika/akhlak yang bertujuan membersihkan diri dari perilaku rendah dan menghiasi diri dengan perilaku terpuji. Pola pelaksanaan Pendidikan Agama Islam kepada Anak Remaja penanaman nilai-nilai agama, membimbing, mengawasi perilaku anak dan menegur mereka apabila melakukan hal yang tidak baik. Terkait dengan meode orang tua dalam membangun akhlak remaja di Desa Air Duku sama saja dengan para orang tua yang lain yaitu dengan cara pembiasaan, nasihat, keteladanan dan perhatian.

\section{Saran}

Mengingat perkembagan usia remaja awal adalah masa transisi dari anak-anak menuju desawa, maka peneliti merekomendasikan kapada setiap orang tua untuk membimbing dan mengawasi anak secara intensif. Apalagi kondisi saat ini di mana arus informasi baik dari web maupun sosial media sangat terbuka dan bebas. Tentu hal tersebut memberikan pengaruh bagi perkembangan usia remaja yang memiliki rasa ingin tahu yang tinggi. 


\section{DAFTAR PUSTAKA}

Abidin, Z., Nurhayati, N. F., \& Lestari, D. A. (2018). Akhlak Mulia Ditinjau Dari Pendidikan Agama Islam dalam keluarga. Prosiding Seminar Nasional Psikologi Unissula, $\quad O(0), \quad$ Article $\quad 0 . \quad$ http://lppmunissula.com/jurnal.unissula.ac.id/index.php/psnpu/article/view/3790

AHMADI, A. (2017). Peran Pendidikan Agama Islam dalam Membina Para Remaja [Diploma, Uin Sultan Maulana Hasanudin Banten]. http://repository.uinbanten.ac.id/633/

Andriyani, I. N. (2016). Pendidikan Islam dalam Keluarga dan Masyarakat. Journal AlManar, 5(1), Article 1. https://doi.org/10.36668/jal.v5i1.16

Arifin, A., \& Karimah, G. (2018). Nilai-Nilai Pendidikan Karakter dalam Novel Madogiwa No Totto-Chan Perspektif KH. Hasyim Asy’ari. Jurnal Pendidikan Islam, 2(2), 240-258.

Asroruddin, M. (2016). Pembinaan Moral Spiritual Siswa Melalui Pembiasaan Shalat Jamaah.Jurnal Al-Amin: Kajian Pendidikan Dan Sosial Kemasyarakatan, 1(1), 72116.

Bali, M. M. E. I., \& Fadli, M. F. S. (2019). Implementasi Nilai-nilai Pendidikan Pesantren dalam Meningkatkan Ketahanan Mental Santri. PALAPA, 7(1), 1-14. https://doi.org/10.36088/palapa.v7i1.164

Basinun, B. (2018). Modernisasi Pendidikan Islam di Indonesia: Respon Muhammadiyah Terhadap Model Pendidikan Barat. At-Ta'lim : Media Informasi Pendidikan Islam, 16(2), 255-275. https://doi.org/10.29300/attalim.v16i2.837

Colorafi, K. J., \& Evans, B. (2016). Qualitative descriptive methods in health science research. HERD: Health Environments Research \& Design Journal, 9(4), 16-25.

Daheri, M., \& Warsah, I. (2019). Pendidikan Akhlak: Relasi Antara Sekolah dengan Keluarga. At-Turats: Jurnal Pemikiran Pendidikan Islam, 13(2), 1-20.

Fachri, M. (2014). Urgensi Pendidikan Agama Islam dalam Pembentukan Karakter Bangsa. AT-TURAS: Jurnal Studi KeIslaman, 1(1), Article 1. https://doi.org/10.33650/at-turas.v1i1.156

Fadlillah, M. (2017). Aliran Progresivisme Dalam Pendidikan di Indonesia. Jurnal Dimensi Pendidikan dan Pembelajaran, 5(1), 17-24. https://doi.org/10.24269/dpp.v5i1.322

Feri Musharyadi, M. K. (2017). Tingkat Pemahaman Mahasiswa Terhadap Norma Norma Agama Islam Menggunakan Algoritma K-Means Clustering. Menara Ilmu, 11(78), Article 78. https://doi.org/10.33559/mi.v11i78.576 
Ghani, M. I. M., \& Musa, N. Y. (2018). Tahap Personaliti Beragama Pengguna Tandas Masjid. International Online Journal of Language, Communication, and Humanities, 1(1), 45-56.

Ginanjar, M. H. (2017). Keseimbangan Peran Orang Tua dalam Pembentukan Karakter Anak. Edukasi Islami: Jurnal Pendidikan Islam, 2(03), Article 03. https://doi.org/10.30868/ei.v2i03.27

Hair, M. A., \& Hair, M. A. (2018). Pendidikan Agama Islam Dalam Keluarga dan Masyarakat. AHSANA MEDIA, 4(2), 28-34. https://doi.org/10.31102/ahsana..4.2.2018.28-34

Hashimov, E. (2015). Qualitative Data Analysis: A Methods Sourcebook and The Coding Manual for Qualitative Researchers: Matthew B. Miles, A. Michael Huberman, and Johnny Saldaña. Thousand Oaks, CA: SAGE, 2014. 381 pp. Johnny Saldaña. Thousand Oaks, CA: SAGE, 2013. 303 pp. Taylor \& Francis.

Hendriana, E. C., \& Jacobus, A. (2017). Implementasi Pendidikan Karakter Di Sekolah Melalui Keteladanan Dan Pembiasaan. JPDI (Jurnal Pendidikan Dasar Indonesia), 1(2), 25-29. https://doi.org/10.26737/jpdi.v1i2.262

Heri, T. (2018). Manajemen Pendidikan Islam Berbasis Tauhid. Rausyan Fikr, 14(1), Article 1. http://jurnal.umt.ac.id/index.php/rf/article/view/674

Hidayah, R. N. (2015). Pendidikan Anak Usia Dini Perspektif Ki Hajar Dewantara. AlMabsut: Jurnal Studi Islam dan Sosial, 9(2), 249-258.

Ilyas, R. (2015). Konsep Mashlahah dalam Konsumsi Ditinjau dari Perspektif Ekonomi Islam. Jurnal perspektif ekonomi darussalam, 1(1), 9-24. https://doi.org/10.24815/jped.v1i1.6517

Imelda, A. (2017). Implementasi Pendidikan Nilai Dalam Pendidikan Agama Islam. AlTadzkiyyah: Jurnal Pendidikan Islam, 8(2), 227-247. https://doi.org/10.24042/atjpi.v8i2.2128

Izzah, I. (2018). Peran Pendidikan Agama Islam dalam Membentuk Masyarakat Madani. PEDAGOGIK: Jurnal Pendidikan, 5(1), 50-68.

Khasanah, W., Umarella, S., \& Lating, A. D. (2019). Peranan Remaja Masjid Ar-Rahman Dalam Pembentukan Karakter Remaja Yang Religius di Desa Waekasar Kecamatan Waeapo Kabupaten Buru. Kuttab: Jurnal Ilmiah Mahasiswa, 1(1), 5773. https://doi.org/10.33477/kjim.v1i1.884

Khoiri, Q. (2018). Model Dan Pendekatan Pendidikan Agama Islam Bagi Remaja Di Kelurahan Tengah Padang Kota Bengkulu. Tadrib, 4(2), 301-318. https://doi.org/10.19109/tadrib.v4i2.3064 
Kholidah, L. N. (2015). Pola Integrasi Nilai-Nilai KeIslaman Dalam Pembelajaran Pendidikan Agama Islam Pada Lembaga Pendidikan. At-Ta'dib, 10(2), Article 2. https://doi.org/10.21111/at-tadib.v10i2.459

Magta, M. (2013). Konsep Pendidikan Ki Hajar Dewantara Pada Anak Usia Dini. Jurnal Pendidikan Usia Dini, 7(2), 221-232.

Miles, M. B., Huberman, A. M., \& Saldaña, J. (2014). Qualitative data analysis: A methods sourcebook. 3rd. Thousand Oaks, CA: Sage.

Munjiat, S. M. (2018). Peran Agama Islam dalam Pembentukan Pendidikan Karakter Usia Remaja. Al-Tarbawi Al-Haditsah: Jurnal Pendidikan Islam, 3(1), Article 1. https://doi.org/10.24235/tarbawi.v3i1.2954

Munthoha, P. Z., \& Wekke, I. S. (2017). Pendidikan Akhlak Remaja bagi Keluarga Kelas Menengah Perkotaan. Cendekia: Jurnal Kependidikan Dan Kemasyarakatan, 15(2), 241-263. https://doi.org/10.21154/cendekia.v15i2.1153

Nelliraharti, N., \& Suri, M. (2020). Sosialisasi Penggunaan Media Pembelajaran Permainan Ular Tangga Untuk Melatih Kemampuan Agama Anak di TPA Baitul Munawwarah Gampong Tibang Banda Aceh. Jurnal Pengabdian Kepada $\begin{array}{llll}\text { Masyarakat } \quad \text { (Pendidikan), } & \text { Article }\end{array}$ http://jurnal.uui.ac.id/index.php/jpkmes/article/view/833

Nurfalah, Y. (2018). Penanaman Nilai-Nilai Agama Islam Terhadap Anak Didik. Tribakti: Jurnal Pemikiran KeIslaman, 29(1), 85-99. https://doi.org/10.33367/tribakti.v29i1.567

Padjrin, P. (2016). Pola Asuh Anak dalam Perspektif Pendidikan Islam. Jurnal Intelektualita: KeIslaman, Sosial dan Sains, 5(1), 1-14. https://doi.org/10.19109/intelektualita.v5i1.720

Raco, J. (2018). Metode penelitian kualitatif: Jenis, karakteristik dan keunggulannya. https://doi.org/10.31219/osf.io/mfzuj

Rahardjo, S. D. A. S. W. dan S. (2017). Peningkatan Perilaku Peduli Lingkungan dan Tanggung Jawab Siswa Melalui Model Ejas dengan Pendekatan Science Edutainment. Jurnal Ilmiah Pendidikan Dasar, 4(1), 1-7. https://doi.org/10.30659/pendas.4.1.1-7

Riantory, P. A. (2019). Perkembangan Psikologi Anak Dalam Perpektif Pendidikan Islam. Jurnal Mathlaul Fattah : Jurnal Pendidikan Dan Studi Islam, 10(1), 55-67.

Ridwan, W., \& Ladamay, O. M. M. A. (2020). Peran Guru Pendidikan Agama Islam dalam Pembinaan Akhlakul Karimah Peserta Didik Di Sma Muhammadiyah 8 Cerme Gresik. TAMADDUN, 21(1), 067-076. https://doi.org/10.30587/tamaddun.v21i1.1378 
Rohman, A. (2016). Pembiasaan Sebagai Basis Penanaman Nilai-Nilai Akhlak Remaja. Nadwa, 6(1), 155-178. https://doi.org/10.21580/nw.2012.6.1.462

Sada, H. J. (2017). Kebutuhan Dasar Manusia dalam Perspektif Pendidikan Islam. AlTadzkiyyah: Jurnal Pendidikan Islam, 8(2), 213-226. https://doi.org/10.24042/atjpi.v8i2.2126

Saihu, S. (2020). Konsep Pembaharuan Pendidikan Islam Menurut Fazlurrahman. Andragogi: Jurnal Pendidikan Islam dan Manajemen Pendidikan Islam, 2(1), 8295. https://doi.org/10.36671/andragogi.v2i1.76

Saihu, S., \& Marsiti, M. (2019). Pendidikan Karakter Dalam Upaya Menangkal Radikalisme di SMA Negeri 3 Kota Depok, Jawa Barat. Andragogi: Jurnal Pendidikan Islam dan Manajemen Pendidikan Islam, 1(1), 23-54. https://doi.org/10.36671/andragogi.v1i1.47

Setiawan, A. A., Johan. (2018). Metodologi penelitian kualitatif. CV Jejak (Jejak Publisher).

Siregar, R. (2018). Nilai-Nilai Pendidikan Islam dalam Tradisi Kekeluargaan Batak Angkola. Al-Muaddib: Jurnal Ilmu-Ilmu Sosial dan KeIslaman, 3(2), Article 2. https://doi.org/10.31604/muaddib.v2i2.553

Sugiarto, E. (2017). Menyusun Proposal Penelitian Kualitatif: Skripsi dan Tesis: Suaka Media. Diandra Kreatif.

Supriatna, U. (2018). Upaya Pelaksanaan Nilai-Nilai Akhlak Karimah dalam Pendidikan Nilai Di Tingkat Persekolahan. Jurnal Teladan: Jurnal Ilmu Pendidikan Dan Pembelajaran, 3(1), 1-13.

Syafe'i, I. (2015). Tujuan Pendidikan Islam. Al-Tadzkiyyah: Jurnal Pendidikan Islam, 6(2), 151-166. https://doi.org/10.24042/atjpi.v6i2.1876

Syahroni, S. (2017). Peranan Orang Tua dan Sekolah dalam Pengembangan Karakter Anak Didik. Jurnal Intelektualita: KeIslaman, Sosial dan Sains, 6(1), 13-28. https://doi.org/10.19109/intelektualita.v6i1.1298

Ulya, I. F., Irawati, R., \& Maulana, M. (2016). Peningkatan Kemampuan Koneksi Matematis dan Motivasi Belajar Siswa Menggunakan Pendekatan Kontekstual. Jurnal Pena Ilmiah, 1(1), 121-130. https://doi.org/10.23819/pi.v1i1.2940

Warsah, I. (2018). Pendidikan Keluarga Muslim di Tengah Masyarakat Multi Agama: Antara Sikap Keagamaan Dan Toleransi (Studi di Desa Suro Bali KepahiangBengkulu). Edukasia: Jurnal Penelitian Pendidikan Islam, 13(1), 1-24. https://doi.org/10.21043/edukasia.v13i1.2784

Warsah, I. (2020). Pendidikan Islam dalam Keluarga: Studi Psikologis dan Sosiologis Masyarakat Multi Agama Desa Suro Bali. Tunas Gemilang Press. 